\title{
Long Term Effect of Tillage and Organo-Mineral Fertilizer Application on Phosphorus Dynamics on Ferric Lixisol in Burkina Faso
}

\author{
Alimata Arzouma Bandaogo \\ Institut de l'Environnement et de Recherches Agricoles (INERA), O1 BP 910 Bobo \\ Dioulasso. Burkina Faso
}

Tel : 0022676405453 E-mail: limbandaogo@yahoo.fr

\section{Korodjouma Ouattara}

Institut de l'Environnement et de Recherches Agricoles (INERA), O4 BP 8645 Ouagadougou. Burkina Faso

Tel : 0022670519997 E-mail: korodjouma_ouattara@hotmail.com

Idriss Serme (Corresponding Author)

Institut de l'Environnement et de Recherches Agricoles (INERA), O4 BP 8645 Ouagadougou. Burkina Faso

Tel: 0022670232198 E-mail: sermeidriss@yahoo.fr

Received: July 7, 2020

doi:10.5296/jas.v8i4.17328
Accepted: August 13, 2020

Published: August 16, 2020

URL: https://doi.org/10.5296/jas.v8i4.17328

\begin{abstract}
A Pot experiment was conducted on 30 years long term soils under different soils management to evaluate the effect of organic amendments and soil tillage on phosphorus evolution in Ferric Lixisol. Two (2) levels of incubation with and without sorghum bicolor were used with six (6) treatments: (1) Tillage with animal traction $+10 \mathrm{t}$ manure / ha / year + $100 \mathrm{~kg}$ NPK (14-23-14-6S-1B) / ha + $50 \mathrm{~kg}$ urea $(46 \% \mathrm{~N})$; (2) Tillage with animal traction + $100 \mathrm{~kg}$ NPK (14-23-14-6S-1B) / ha + $50 \mathrm{~kg}$ urea (46\% N); (3) Minimum tillage+ $10 \mathrm{t}$ manure / ha / year + $100 \mathrm{~kg}$ NPK (14-23-14-6S-1B)/ ha + $50 \mathrm{~kg}$ urea $(46 \% \mathrm{~N})$; (4) Minimum
\end{abstract}


tillage + $100 \mathrm{~kg}$ NPK (14-23-14-6S-1B) / ha + $50 \mathrm{~kg}$ urea (46\% N); (5) 30-years-old fallow and (6) control plot (continuous sorghum without fertilizer) from soil fertility sustainability trial. Each treatment was pretreated with carbon plus nitrogen or without nitrogen before the experiment. The results showed that tillage increased P availability by 70 to $273 \%$ compared to fallow in general and the use of organic matter improved only $\mathrm{P}-\mathrm{NaHCO}_{3}$ by $83 \%$. The effect of nutrient (carbon and nitrogen) addition varied according to different fraction of $\mathrm{P}$. P-NaHCO 3 with sorghum incubation seems to be more responsive to nutrient addition. Therefore, minimum tillage with organic and mineral fertilizers amendments has beneficial effect on available $\mathrm{P}$ fractions.

Keywords: long term cultivation, tillage, phosphorus availability, carbon and nitrogen

\section{Introduction}

Improper agricultural practices contribute to natural resources and soil degradation (Nasir Ahmad et al., 2020; Ayub et al., 2020). The degradation of natural resources, particularly of soils, remains a major problem for agro-sylvo-pastoral sustainability in the Sudano-Sahelian zones (Lal, 1997). Improper management practices negatively affect soil health (depletion of organic matter and other nutrients) as well as decline in crop productivity (Ramos et al., 2011). This decline in soil fertility results also, in depletion of soils phosphorus. There are three major pathways of $\mathrm{P}$ loss from soil: erosion, leaching both non-intended and sometimes mutually interlinked, and the uptake by plants and removal with harvests. Phosphorus $(\mathrm{P})$ is the second most important macronutrient as an essential plant nutrient. It is a key nutrient for sustainable agricultural productivity and which limits plant growth in many soils (Scervino et al., 2011). In fact, when soil phosphorus is removed by plants, bioavailable phosphorus becomes limiting. Therefore, a sustainable agricultural system requires replenishment of this nutrient to increase the levels of bioavailable phosphorus (Compaoré, 1996). Major global problems related to soil phosphorus in Burkina Faso $(\mathrm{P})$ are the limited plant productivity caused by its low availability and high fixation in soils (Sédogo, 1995). Phosphorus deficiency in tropical Lixisol can be caused by the nature of the geological substratum, the evolution during the formation of soil, and also by the low organic matter content and the rapid soils depletion after cultivation (Sédogo et al., 1991; Eduah, 2019). Inorganic fertilizer is widely used in agriculture to increase soil nutrient and soil productivity. Soil tillage is among the important factors affecting soil properties and crop yield. Among the crop production factors, tillage contributes up to $20 \%$ (Derpsch et al., 2010). Organic matter has a favourable effect on $\mathrm{P}$ dynamics of the soil; in addition to $\mathrm{P}$ release by mineralization, the competition of organic ligands for $\mathrm{Fe}$ and $\mathrm{Al}$ oxides surface can result in a decrease in $\mathrm{P}$ fixation of applied and native P. Organic carbon plays a central role in the inherent soil fertility through mineralization of soil organic matter which occurs in tropical areas as Burkina Faso with about $2 \%$ of the carbon stock per year (Pieri, 1989).

Phosphorus mobility in soils has been commonly studied by quantifying $\mathrm{P}$ in different extracts to assess its lability. For soils, $\mathrm{H}_{2} \mathrm{O}$ or resin extractable $\mathrm{P}$ are thought to be composed of dissolved inorganic $\mathrm{P}$, whereas $\mathrm{NaHCO}_{3}$ and $\mathrm{NaOH}$ extractable fractions may be a mixture of amorphous and crystalline $\mathrm{Al}$ and $\mathrm{Fe}$ phosphates and some physically and chemically 


\section{Ml Macrothink}

protected organic $\mathrm{P}$ (Toor et al, 2006). Compared to nitrogen, tillage system and its relationship with phosphorus availability have received less attention. Long-term experiments are useful to assess the evolution in soil quality induced by the adoption of cropping systems, soil management practices, fertilizer application, or organic matter management. This paper aims at studying the effect of organic amendments and soil tillage on phosphorus evolution on a Ferric Lixisol.

\section{Materials and Methods}

Site and Trial Description

The support of this study is a long-term trial "Soil Physical Study Trial" installed since 1990 at the Institute of Environment and Agricultural Research Station of Saria (12 $\left.16^{\prime} \mathrm{N}, 2^{\circ} 9^{\prime} \mathrm{W}\right)$ in Burkina Faso. The trial site is located in a north-Sudanian climate (Fontès and Guinko, 1995) with an average daily temperature varying from $30{ }^{\circ} \mathrm{C}$ during the rainy season to $45{ }^{\circ} \mathrm{C}$ in April and May. The rainfall is confined to the period from May to October with an annual mean of $800 \mathrm{~mm}$. The main species of natural vegetation are Parkia biglobosa, Vitellaria paradoxa, Tamarindus indica, Andropogon gayanus and Pennisetum pedicellatum. The soil is Ferric Lixisol (FAO, 2006). Soil in the study area is mainly poor with low organic carbon (SOC), $\mathrm{N}$ and available $\mathrm{P}$ contents (Table 1).

Table 1. Soil physical and chemical properties

\begin{tabular}{|c|c|}
\hline Physico-chemical characteristics & CONTENT \\
\hline \multicolumn{2}{|l|}{ Texture $(\%)$ : } \\
\hline Coarse sand & 22 \\
\hline Fine sand & 31 \\
\hline Coarse silt & 28 \\
\hline Fine silt & 8 \\
\hline Clay & 11 \\
\hline Total Carbon $\left(\mathrm{mg} \mathrm{kg}^{-1}\right)$ & 0.39 \\
\hline Total Nitrogen $\left(\mathrm{g} \mathrm{kg}^{-1}\right)$ & 0.03 \\
\hline \multicolumn{2}{|l|}{ Cation $(\mathbf{c ~ m o l ~ k g - 1})$} \\
\hline $\mathrm{Ca}^{++}$ & 1.99 \\
\hline $\mathrm{Mg}^{++}$ & 0.67 \\
\hline $\mathrm{Na}^{++}$ & 0.00 \\
\hline $\mathrm{K}^{+}$ & 0.09 \\
\hline Sum of bases (S) & 2.75 \\
\hline Cation exchange capacity & 4.96 \\
\hline Saturation (S/T x 100) & 57.00 \\
\hline pH Water & 6.4 \\
\hline Total Phosphorus (mg Kg-1) & 67.28 \\
\hline
\end{tabular}

The Experiment design used in the long-term trial is a Fisher block. It consists of three blocks 
(or repetitions) each incorporating two parameters, namely tillage and organic amendment. Each block is divided into four elementary plots where two types of soil tillage are combined with two levels of organic amendments. The treatments are defined as follow:

T1-MO: Tillage with animal traction $+10 \mathrm{t}$ cow dung manure / ha / year $+100 \mathrm{~kg}$ NPK $(14-23-14-6 \mathrm{~S}-1 \mathrm{~B}) / \mathrm{ha}+50 \mathrm{~kg}$ urea $(46 \% \mathrm{~N})$;

T1: Tillage with animal traction $+100 \mathrm{~kg}$ NPK $(14-23-14-6 \mathrm{~S}-1 \mathrm{~B}) / \mathrm{ha}+50 \mathrm{~kg}$ urea $(46 \% \mathrm{~N})$;

T3-MO: Minimum tillage+ $10 \mathrm{t}$ cow dung manure / ha / year $+100 \mathrm{~kg}$ NPK $(14-23-14-6 \mathrm{~S}-1 \mathrm{~B}) / \mathrm{ha}+50 \mathrm{~kg}$ urea $(46 \% \mathrm{~N})$;

T3: Minimum tillage + $100 \mathrm{~kg}$ NPK (14-23-14-6S-1B)/ ha $+50 \mathrm{~kg}$ urea $(46 \% \mathrm{~N})$.

Two other treatments were added to the experiment as reference such as:

F: 30-years-old fallow that was served as base and

C: Control plot (continuous sorghum without fertilizer) of soil fertility sustainability trial.

This experiment was conducted in pot experiment using soil from the long-term trial with the six treatments cited earlier (T1, T1-MO, T3, T3-MO, C and F). It was conducted in 4 repetitions in pots containing $100 \mathrm{~g}$ of soil each and before plant sowing three types of pretreatments was applied to each treatment. The pretreatments were carbon $(5 \mathrm{~g}$ supply in form of glucose); carbon and nitrogen ( $0.1 \mathrm{~g}$ in form of ammonium sulfate) and no nutrient supply. Two levels of incubation with sorghum and without sorghum were used with the different treatments. Sorghum variety Sariasso 14 was used for the experiment. The duration of the incubation was 4-6 weeks depending on the vegetative stage of plant. Fractionation of phosphorus was done on soil samples before incubation, and one, two and six weeks after incubation from pots without sorghum crop and on the plant material. Plant was irrigated with distilled water to avoid any nutrient supply.

Soil chemical analysis: soil pH (ratio of 1: 2.5) was measured according to Afnor standards, 1981). Soil organic carbon content $\left(\mathrm{mg} \mathrm{C} \mathrm{kg}^{-1}\right.$ Soil) was assessed using the Walkley and Black, 1934 method. Soil organic matter and carbon contents were determined by the equation:

$$
\mathrm{C}\left(\mathrm{mg} \mathrm{kg}^{-1}\right)=\frac{10-\mathrm{V} \times \mathrm{T}}{\mathrm{PE}} \times 3,9
$$

Where, $\mathrm{T}=10 / \mathrm{V}^{\prime}\left(10=\right.$ volume of $\mathrm{K}_{2} \mathrm{Cr}_{2} \mathrm{O}_{7}$ for white and $\mathrm{V}^{\prime}=$ volume of Mohr salt used for determination of white).

$\mathrm{T}=$ Mohr salt for titration

$\mathrm{V}=$ Mohr salt volume for the determination of the sample $(\mathrm{ml})$

$\mathrm{PE}=$ soil test sample $(\mathrm{g})$ and 


$$
\text { MO }(\%)=\mathrm{C}\left(\mathrm{mg} \mathrm{kg}^{-1}\right) \times 0,1724
$$

To determine the total nitrogen $(\mathrm{N})$ and potassium $(\mathrm{K})$ contents, soil samples were first hot-mineralized with an $\mathrm{H}_{2} \mathrm{SO}_{4}-\mathrm{Se}-\mathrm{H}_{2} \mathrm{O}_{2}$ mixture. Total nitrogen was determined using an automatic colorimeter (Skalar SANplus Segmented Flow Analyzer, Model 4000-02, Holland), while total $\mathrm{K}$ was determined by flame photometry. Total $\mathrm{P}$ levels were determined by mineralizing soil samples, according to the Kjedhal method, using a concentrated $\mathrm{H}_{2} \mathrm{SO}_{4}$ acid solution in the presence of selenium catalyst and $\mathrm{H}_{2} \mathrm{O}_{2}$. The total phosphorus contents are then determined in the mineralizers using a SKALAR automatic colorimeter (Segmented flow analyzer, model SANplus 4000-02, Skalar Holland).

\section{Fractionation of phosphorus}

Hedley et al. (1982) method was used for phosphorus fractionation. The Hedley fractionation recognizes plant-available forms (Resin $\mathrm{Pi}$, Bicarbonate $\mathrm{Pi}$, and Bicarbinate $\mathrm{Po}$ ) and refractory forms $(\mathrm{NaOH} \mathrm{Pi}, \mathrm{NaOH} \mathrm{Po}$, sonic $\mathrm{Pi}$, sonic $\mathrm{Po}, \mathrm{HCl} \mathrm{Pi}$, and Residual $\mathrm{P}$ ) of soil phosphorus. The soil samples were weighed to $4 \mathrm{~g}$ and are agitated for 16 hours in $20 \mathrm{ml}$ of distilled water with 2 anionic membranes saturated with bicarbonate. The membranes have an area of $2 \mathrm{~cm}^{2}(1 \mathrm{~cm} \times 2 \mathrm{~cm})$. To release the P set by the membranes, they were removed and agitated in $20 \mathrm{ml}$ of $0.5 \mathrm{M} \mathrm{HCl}$ for 30 minutes. The obtained solution was sequentially agitated for $16 \mathrm{~h}$ in $20 \mathrm{ml}$ of buffered $0.5 \mathrm{M} \mathrm{NaHCO}_{3}$ and $0.5 \mathrm{M} \mathrm{NaOH}$ at $\mathrm{pH}$ 8.5. After centrifugation and filtration, inorganic $\mathrm{P}\left(\mathrm{P}-\mathrm{NaHCO}_{3}\right.$ and $\left.\mathrm{P}-\mathrm{NaOH}\right)$ were determined by acid digestion by autoclaving in $10 \mathrm{ml}$ of $\mathrm{H}_{2} \mathrm{SO}_{4}$ and $0.5 \mathrm{~g}$ of $\mathrm{K}_{2} \mathrm{~S}_{2} \mathrm{O}_{8}$. The same procedure was used for the determination of $\mathrm{P}-\mathrm{HCl}$ after sharing the solution in $1.0 \mathrm{M} \mathrm{HCl}$. P-resin was extracted by Acid mineralization in $10 \mathrm{ml}$ of $\mathrm{H}_{2} \mathrm{SO}_{4}$ and $0.5 \mathrm{~g}$ of $\mathrm{K}_{2} \mathrm{~S}_{2} \mathrm{O}_{8}$.

Statistical analysis

The results were subjected to analysis of variance using Genstat $9^{\text {th }}$ edition. Significant treatment means of each soil were identified by using the least significant differences (LSD) value at $5 \%$ level of probability for $\mathrm{P}$ source, time and incubation.

\section{Results}

Soil tillage with soil amendment significantly $(\mathrm{p}<0001)$ increased $\mathrm{P}$ availability compared to fallow and the control (Table 2). Higher amount of $\mathrm{P}$ was observed with T1 (tillage with animal traction $+100 \mathrm{~kg}$ NPK $(14-23-14-6 \mathrm{~S}-1 \mathrm{~B}) / \mathrm{ha}+50 \mathrm{~kg}$ urea $(46 \% \mathrm{~N}))$ for all $\mathrm{P}$ sources except from $\mathrm{P}_{-} \mathrm{NaHCO}_{3}$ (with sorghum). The values are ranged from $20.26 \mathrm{mg} \mathrm{Kg}^{-1}$ to 35.24 $\mathrm{mg} \mathrm{Kg}{ }^{-1}$ with the incubation of sorghum and from $12.77 \mathrm{mg} \mathrm{kg}^{-1}$ to $32.4 \mathrm{mg} \mathrm{kg}^{-1}$ with no incubation of sorghum. The highest $\mathrm{P}$ amount was observed with $\mathrm{P}-\mathrm{NaOH}$ fraction $(35.24 \mathrm{mg}$ $\mathrm{Kg}^{-1}$ ). Phosphorus extracted with $\mathrm{NaOH}$ was greater in all cropping systems compared to $\mathrm{P}-\mathrm{HCl}, \mathrm{P}$-resin and $\mathrm{P}-\mathrm{NaHCO}_{3}$ in general. It was also observed that soil incubation has a positive effect on $\mathrm{P}$ availability. The results showed that soil planted with sorghum has increased $\mathrm{P}$ availability compared to non-incubated soil. The used of organic matter significantly increasing only $\mathrm{P}-\mathrm{NaHCO}_{3}$ content by $83 \%$ on tillage with animal traction treatment. Addition of mineral fertilizer significantly improved $\mathrm{P}$ different fraction in general. 


\section{Macrothink Institute ${ }^{\mathrm{TM}}$}

$\mathrm{P}-\mathrm{HCl}$ was increased by 57 to $138 \%$ and $\mathrm{P}-\mathrm{NaOH}$ increased more than $20 \%$ when mineral fertilizer application is combined with soil tillage.

Table 2. Effect of soil tillage and amendments on phosphorus availability ( $\left.\mathrm{mg} \mathrm{Kg}^{-1}\right)$

\begin{tabular}{|c|c|c|c|c|c|c|c|c|c|}
\hline & Treatment & Fallow & control & T1-MO & $\mathrm{T} 1$ & T3-MO & $\mathrm{T} 3$ & Lsd & $\mathrm{P}<\mathrm{F}$ \\
\hline \multirow[t]{4}{*}{ Sorghum } & $\mathrm{HCl}$ & $5,86 \mathrm{c}$ & $5,25 \mathrm{c}$ & $8,99 \mathrm{c}$ & $21,39 a$ & $9,88 \mathrm{~cd}$ & $15,56 \mathrm{~b}$ & 3,83 & $\mathrm{P}<001$ \\
\hline & Resin & $11,94 b$ & $12,54 \mathrm{~b}$ & $19,17 \mathrm{a}$ & $20,26 a$ & $12,38 b$ & $15,19 \mathrm{~b}$ & 3,51 & $\mathrm{P}<001$ \\
\hline & NAHCO3 & $16,73 b$ & $17,45 b$ & $24,17 \mathrm{a}$ & $13,23 b$ & $17,62 b$ & $15,57 b$ & 4,56 & $\mathrm{P}<001$ \\
\hline & $\mathrm{NaOH}$ & $25,64 b$ & $27,20 \mathrm{~b}$ & $29,19 b$ & $35,24 a$ & $24,95 b$ & $30,44 a$ & 5,44 & $\mathrm{P}<001$ \\
\hline No & $\mathrm{HCl}$ & $4,99 \mathrm{~b}$ & $3,82 \mathrm{~b}$ & $9,24 b$ & $23,04 a$ & $9,70 \mathrm{~b}$ & $17,62 \mathrm{a}$ & 5,62 & $\mathrm{p}<001$ \\
\hline \multirow[t]{3}{*}{ sorghum } & Resin & $4,99 \mathrm{c}$ & $2,90 \mathrm{c}$ & $8,42 b$ & $12,77 \mathrm{a}$ & $8,45 b$ & $11,21 \mathrm{a}$ & 2,13 & $\mathrm{P}<001$ \\
\hline & NAHCO3 & $10,73 \mathrm{c}$ & $6,279 \mathrm{~d}$ & $13,95 \mathrm{~b}$ & $17,79 a$ & $10,81 \mathrm{c}$ & $15,98 \mathrm{ab}$ & 2,29 & $\mathrm{p}<001$ \\
\hline & $\mathrm{NaOH}$ & $20,81 b$ & $19,90 \mathrm{~b}$ & $31,12 \mathrm{a}$ & $32,02 \mathrm{a}$ & $23,04 b$ & $30,17 \mathrm{a}$ & 6,00 & $\mathrm{P}<001$ \\
\hline
\end{tabular}

Soil phosphorus availability varied significantly $(\mathrm{P}<0.001)$ with different soil management (Table 3). Phosphorus content was high with the used of organic matter in all the treatments. Organic matter application increased $\mathrm{P}-\mathrm{HCl}$ and $\mathrm{P}-\mathrm{NaHCO}_{3}$ by $33 \%$ and $16 \%$ over the control and the fallow practice, respectively. The result also showed low $\mathrm{P}$ content with the use of mineral fertilizer compared to the other treatments.

Table 3. Phosphorus content in different soil management

\begin{tabular}{lllllll}
\hline Treatment & Control & Fallow & OM & MF & P $<F$ & LSD \\
\hline P-HCl $\left(\mathrm{mg} \mathrm{Kg}^{-1}\right)$ & $12,27 \mathrm{~b}$ & $12,27 \mathrm{~b}$ & $16,79 \mathrm{a}$ & $7,75 \mathrm{c}$ & $<0001$ & 2,48 \\
$\mathrm{P}-\mathrm{Resin}\left(\mathrm{mg} \mathrm{Kg}^{-1}\right)$ & 15,85 & 15,85 & 16,82 & 14,87 & $\mathrm{NS}$ & \\
$\mathrm{P}-\mathrm{NaOH}\left(\mathrm{mg} \mathrm{Kg}^{-1}\right)$ & 29,25 & 29,25 & 32,13 & 26,36 & $\mathrm{NS}$ & \\
$\mathrm{P}-\mathrm{NaHCO}_{3}\left(\mathrm{mg} \mathrm{Kg}^{-1}\right)$ & $17,72 \mathrm{ab}$ & $17,72 \mathrm{ab}$ & $20,50 \mathrm{a}$ & $14,95 \mathrm{~b}$ & 0,01 & 3,14 \\
\hline
\end{tabular}

Phosphorus availability responses to the type of nutrient application were different among the treatments. The supply of carbon and nitrogen or carbon alone did not significantly affect phosphorus availability for $\mathrm{P}-\mathrm{HCl}, \mathrm{P}-\mathrm{NaOH}$ and $\mathrm{P}-\mathrm{NaHCO}_{3}$ even though the supply of nutrient increased $\mathrm{P}$ availability, generally (Table 4). Only P-resin was significantly ( $<<0.001$ ) affected by nutrient application. Addition of carbon and nitrogen increased both the control and the fallow practice soils P-resin content by $53 \%$ and $51 \%$, respectively, compared to the 
no nutrient application treatment. Addition of nutrient did not increase soil P-resin content with tillage.

Table 4. Effect of soil tillage and nutrient on P availability

\begin{tabular}{|c|c|c|c|c|c|}
\hline \multicolumn{2}{|l|}{ Treatments } & $\mathrm{P}-\mathrm{HCl}$ & P-Resin & $\mathrm{P}-\mathrm{NaOH}$ & $\mathrm{P}-\mathrm{NaHCO}_{3}$ \\
\hline & & \multicolumn{4}{|c|}{$\left(\mathrm{mg} \mathrm{Kg}{ }^{-1}\right)$} \\
\hline \multirow[t]{3}{*}{ Control } & Carbon & 6.60 & $14.12 \mathrm{bc}$ & 34.24 & 20.26 \\
\hline & Carbon_Nirogen & 4.96 & $14.21 \mathrm{bc}$ & 23.35 & 17.18 \\
\hline & No_nutrients & 4.17 & $9.29 \mathrm{~cd}$ & 23.99 & 9.28 \\
\hline \multirow[t]{3}{*}{ Fallow } & Carbon & 5.83 & $7.59 \mathrm{~d}$ & 23.18 & 16.72 \\
\hline & Carbon_Nirogen & 6.06 & $16.98 \mathrm{ab}$ & 31.52 & 23.09 \\
\hline & No_nutrients & 5.69 & $11.25 \mathrm{bc}$ & 22.22 & 10.39 \\
\hline \multirow[t]{3}{*}{ soil scraping } & Carbon & 15.64 & $18.68 \mathrm{ab}$ & 31.87 & 21.76 \\
\hline & Carbon_Nirogen & 12.94 & $16.55 \mathrm{ab}$ & 32.95 & 21.84 \\
\hline & No_nutrients & 16.97 & $23.90 \mathrm{a}$ & 31.82 & 18.83 \\
\hline \multirow[t]{3}{*}{ Soil ploughing } & Carbon & 15.25 & $12.10 \mathrm{bc}$ & 25.74 & 15.61 \\
\hline & Carbon_Nirogen & 10.93 & $12.73 b c$ & 30.33 & 15.80 \\
\hline & No_nutrients & 11.98 & $16.52 \mathrm{ab}$ & 27.02 & 14.87 \\
\hline $\mathrm{P}<\mathrm{F}$ & & NS & 0,04 & NS & NS \\
\hline $\operatorname{LSD}(5 \%)$ & & & 7,51 & & \\
\hline
\end{tabular}

Nutrient application did not significantly increased phosphorus availability when sorghum is not inoculated. Significant effect $(\mathrm{P}<0.001)$ was observed only with $\mathrm{P}-$ resin and $\mathrm{P}-\mathrm{NaHCO}_{3}$ content with sorghum. Phosphorus availability increased until two weeks after carbon and nitrogen or carbon application and decreased until the end of the experiment for both P-resin and $\mathrm{P}-\mathrm{NaHCO}_{3}$ content (Figure 1 and 2). The P-resin content did not improve when nutrient is added. The highest amount $\left(26.5 \mathrm{mg} \mathrm{Kg}^{-1}\right)$ and the lowest amount $\left(21.7 \mathrm{mg} \mathrm{Kg}^{-1}\right)$ of P-resin content after two weeks were observed with no nutrient treatment and carbon 


\section{Macrothink}

treatment, respectively. Carbonate $\mathrm{P}$ increase with the used of nitrogen and carbon or carbon and the maximum amounts were obtained two weeks after application. The used of carbon alone improved $\mathrm{P}_{-} \mathrm{NaHCO}_{3}\left(24.1 \mathrm{mg} \mathrm{Kg}{ }^{-1}\right)$ compared to the combination of nitrogen and carbon $\left(21.1 \mathrm{mg} \mathrm{Kg}^{-1}\right)$ after 2 weeks.

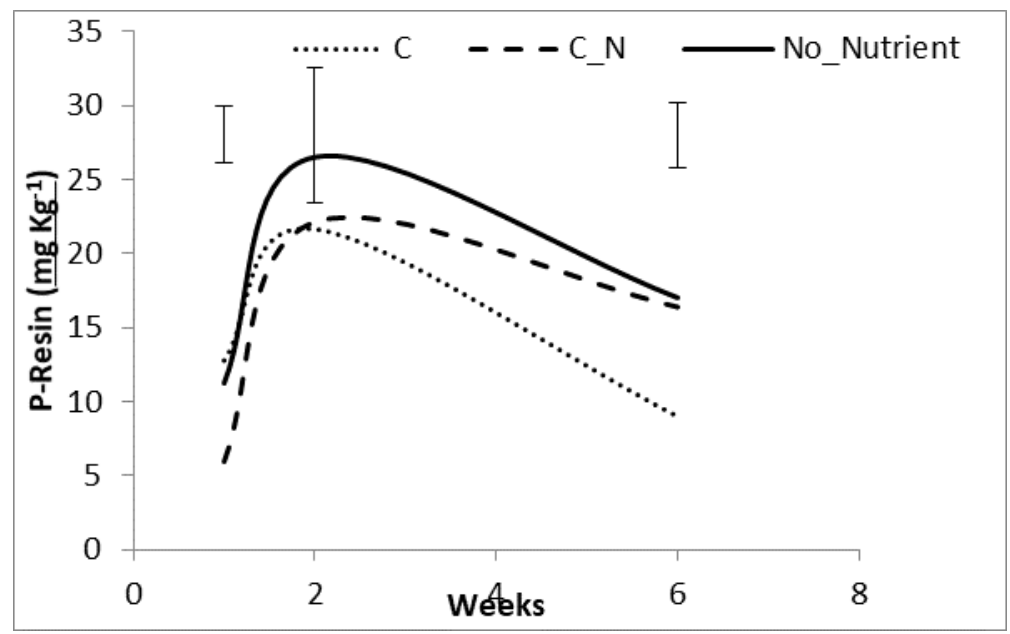

Figure1. Evolution of P-Resin after nitrogen and / or carbon application

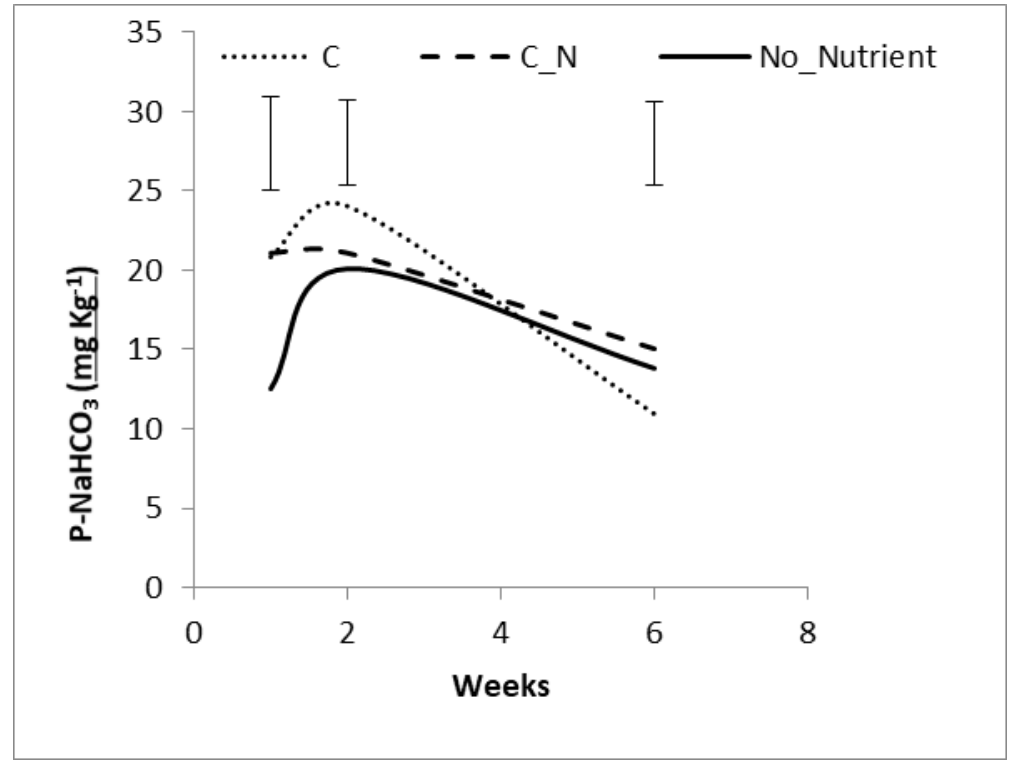

Figure 2. Evolution of $\mathrm{P}-\mathrm{NaHCO}_{3}$ after nitrogen and / or carbon application

\section{Discussion}

Phosphorus availability increased $(\mathrm{P}<0.001)$ with tillage and application of mineral fertilizer, in general. Soil phoughing with sorghum incubation increased $\mathrm{P}-\mathrm{NaOH}, \mathrm{P}-$ resin and $\mathrm{P}-\mathrm{HCl}$, by $37 \%, 70 \%$, and $273 \%$, compared to fallow, respectively. Tillage has various physical, chemical and biological effects on soil depending on the appropriateness or otherwise of the methods used. Soil tillage can reduce soil drainage and improve soil structure. This condition can develop better condition for microbial activities for the mineralization of phosphorus. Management practices that improve soil aggregation may therefore have benefits for soil $\mathrm{P}$ 
availability (Andrew et al, 2017; Barro, 1997). The use of organic matter together with soil phoughing improved $\mathrm{P}_{-} \mathrm{NaHCO}_{3}$ by $83 \%$ unlike the other form of $\mathrm{P}$. Phosphorus derived from $\mathrm{NaOH}$, resin and $\mathrm{HCl}$ were greater with the use of mineral fertilizer. This can be explained by the fact that $\mathrm{P}$ added from manure tends to become less available to plants in long term (Sample et al., 1980, Lemming et al., 2019). Depending of the status of P fertilizer in soil, manure and mineral fertilizer appear to contribute to different $\mathrm{P}$ pools (Griffin et al 2003).

The use of organic matter improved $\mathrm{P}-\mathrm{HCl}$ and $\mathrm{P}-\mathrm{NaHCO} 3$ by $33 \%$ and $16 \%$ over the control and fallow, respectively. These results are in agreement with those reported by Sharpley and Smith (1995) and Shafqat and Pierzynski (2010) who found that continuous application of organic matter significantly increased $\mathrm{P}-\mathrm{NaHCO}_{3}$ and $\mathrm{P}-\mathrm{HCl}$. The application of organic matter increases soil $\mathrm{P}$ solubility, decreases $\mathrm{P}$ fixation, and thus improves $\mathrm{P}$ availability to plants as reported by Khiari and Parent (2005) and Soma et al., (2018). Soil colloids are also essential for the P adsorption and availability (Dhillon, 2004, Pratap, 2015). Manure application increase soil fertility, especially in the Sudano-Sahelian region where nutrient depleted and weathered soils are typically managed with low input (Ouédraogo et al., 2001).

Soil incubation with sorghum positively influenced soil P availability. Lal and Steward (2016) reported that plants and their symbionts directly acidify soil environment by the exudation of organic acids and chelating agents, promoting and make $\mathrm{P}$ occluded in secondary minerals available.

Pretreatment of soil with nitrogen and carbon associated with soil management significantly affected P-resin, only. Addition of carbon and nitrogen increased both the control and fallow P-resin by $53 \%$ and $51 \%$, respectively, compared to no nutrient added.

\section{Conclusion}

Long term effect of tillage and soil amendments had significant effect on different soil $\mathrm{P}$ fraction. Reduced tillage in conjunction with organic and mineral amendment improved soil phosphorus availability by 70 to $273 \%$ compared to fallow and soil under continous cultivation. The increase occurred mainly when soil is incubated with sorghum. Addition of carbon and nitrogen improved soil $\mathrm{P}$ availability under soil incubated with sorghum. Reduced tillage with organic and mineral fertilizers amendments can be used to increase P availability under sorghum cropping system.

\section{References}

AFNOR. (1981). Détermination du pH. (Association française de normalisation) NF ISO 103 90. In AFNOR Qualité des sols, Paris, 339-348.

Andrew J. Margenot, Birthe KPSommer, RR., Pulleman MM., Parikh, S. J., ... Fonte, S. J. (2017). Can conservation agriculture improve phosphorus (P) availability in weathered soils? Effects of tillage and residue management on soil P status after 9 years in a Kenyan Oxisol. Soil and Tillage Research, ISSN: 0167-1987, 166, 157-166. 
https://doi.org/10.1016/j.still.2016.09.003

Ayub M. A., Usman M., Faiz T., Umair M., ul Haq M. A., Rizwan M., ... Rehman M. Z. (2020). Restoration of Degraded Soil for Sustainable Agriculture. In Soil Health Restoration and Management. Springer, Singapore, 31-81. https://doi.org/10.1007/978-981-13-8570-4_2

Barro, A. (1997). Effet du travail du sol en sec à la dent Rs8 sur l'amélioration de la production du sorgho au Burkina Faso. In: Pirot, R., Perret, S., Manichon, H. (Eds.), Le travail du sol dans les systèmes mécanisés tropicaux. Collection Colloques, CIRAD-Sar, Montpellier, France, pp. 61-63.

Compaoré, N. E. (1996). Contribution à la caractérisation et à la gestion de la fertilité phosphatée de quelques sols ferrugineux tropicaux. Thèse de Doctorat, INPL. NANCY : 134 pp.

Derpsch, R., Friedrich, T., Kassam, A., \& Hongwen, L. (2010). Current status of adoption of no-till farming in the worls and some of its main benefits. International Journal of Agricultural and Biological Engineering, 3(1).

Dhillon, N. S., Dhesi, T. S., \& Brar, B. S. (2004). Phosphate sorption-desorption characteristics of some Ustifluvents of Punjab. J. Indian Soc. Soil Sci., 52, 17-22.

Eduah, J. O., Nartey, E. K., Abekoe, M. K., Breuning-Madsen, H., \& Andersen, M. N. (2019). Phosphorus retention and availability in three contrasting soils amended with rice husk and corn cob biochar at varying pyrolysis temperatures. Geoderma, 341, 10-17. https://doi.org/10.1016/j.geoderma.2019.01.016

FAO (2006). World Reference Base for Soil Resources 2006: A Framework for International Classification, Correlation and Communication, World Soil Resources Reports 103. FAO, Rome.

Fontès, J., \& Guinko, S. (1995). Carte de la végétation et de l'occupation du sol du Burkina Faso. Note Explicative. Ministère de la coopération française, Toulouse.

Griffin, T. S., Honeycutt, C. W., \& He, Z. (2003). Changes in soil phosphorus from manure application. Soil Science Society of America Journal, 67, 645-653. https://doi.org/10.2136/sssaj2003.6450

Hedley, M. J., Stewart, J. W. B., \& Chauhan, B. S. (1982). Changes inorganic and organic soil phosphorus fractions induced by culti-vation practices and laboratory incubations. Soil Sci. Soc. Am. J., 46, 970-976. https://doi.org/10.2136/sssaj1982.03615995004600050017x

Khiari, L., \& Parent, L. E. (2005). Phosphorus transformations in acid light-textured soils treated with dry swine manure, Can. J.Soil Sci., 85, 75-87. https://doi.org/10.4141/S03-049

Lal, R., \& Stewart, B. A. (2016). Soil Phosphorus, CRC Press, Milton. ISBN 9781482257847, 344p. https://doi.org/10.1201/9781315372327

Lal, R., Blum, W. E. H., Valentin, C., \& Stewart, B. A. (1997). Methods for Assessment of Land Degradation. Boca Raton: CRC. 
Lemming, C., Oberson, A., Magid, J., Bruun, S., Scheutz, C., Frossard, E., \& Jensen, L. S. (2019). Residual phosphorus availability after long-term soil application of organic waste. Agriculture, ecosystems \& environment, 270, 65-75. https://doi.org/10.1016/j.agee.2018.10.009

Nasir Ahmad, N. S. B., Mustafa, F. B., Yussoff, S. Y. M., \& Didams, G. (2020). A systematic review of soil erosion control practices on the agricultural land in Asia. International Soil and Water Conservation Research, 8, 103-115. https://doi.org/10.1016/j.iswcr.2020.04.001

Ouédraogo E., A. Mando, \& Zombré N.P. (2001). On-farm effect of compost on carbon sequestration and sorghum performance in Burkina Faso, West Africa. Agric. Ecosyst. Environ., 21, 25-36.

Pieri, C. (1989). Fertilité des terres de savane. Bilan de 30 années de recherche et de développement agricoles au sud du sahara. Paris: Agridoc-International. Ministère de la coopération et CIRAD-IRAT. 444p.

Pratap, B., Nayak, A. K., Shahid, M., Tripathi, R., Mohanty, S., Kumar, A, ... Dash, P. K. (2015). Effects of 42-year long-term fertilizer management on soil phosphorus availability, fractionation, adsorption-desorption isotherm and plant uptake in flooded tropical rice. The Crop Journal, 3, 387-395. https://doi.org/10.1016/j.cj.2015.03.009

Ramos, M. E., Robles, A. B., Sánchez-Navarro, A., \& González-Rebollar, J. L. (2011). Soil responses to different management practices in rainfed orchards in semiarid environments. Soil and Tillage Research, 112(1), 85-91. https://doi.org/10.1016/j.still.2010.11.007

Sample, E. C., Soper, R. J., \& Racz, G. J. (1980). Reaction of phosphate fertilizer in soil. In: Khasawneh EF, Sample EC, Kamprath EJ, editor. The Role of Phosphorus in Agriculture. WI: American Society of Agronomy, 263-310.

Scervino, J. M., Papinutti, V. L., Godoy, M. S., Rodriguez, J. M., Monica, I. D., Recchi, M., ... Godeas, A. M. (2011). Medium pH, carbon and nitrogen concentrations modulate the phosphate solubilization efficiency of Penicillium purpurogenum through organic acid

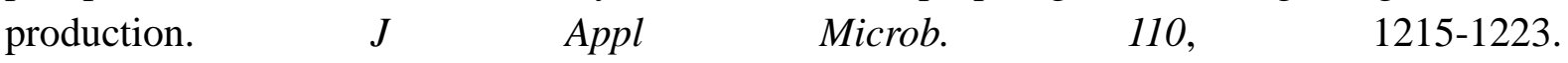
https://doi.org/10.1111/j.1365-2672.2011.04972.x

Sédogo, M. P. (1995). Étude de la variabilité génétique d'une collection de mil (Pennisetum glaucum (L.) R. Br.) du Burkina. Thèse de Doctorat d'ingénieur, Université Nationale de Côte d'Ivoire.

Sédogo, M. P., Bado, B. V., Hien, V., \& Lompo, F. (1991). Utilisation efficace des engrais azotés pour une augmentation de la production vivrière : L'expérience du Burkina Faso. In: Alleviating soil fertility constraints to increased crop production in West Africa. A. Mokwunye (ed). Kluwer Academic Publishers, Dordrecht, 115-123. https://doi.org/10.1007/978-94-011-3224-4_10

Shafqat, N., \& Pierzynski, G. M. (2010). Long-Term Effects of Tillage and Manure Applications on Soil Phosphorus Fractions. Communications in Soil Science and Plantn 
Analysis, 41(9), 1084-1097. https://doi.org/10.1080/00103621003687174

Sharpley, A. N., \& Smith, S. I. (1995). Nitrogen and phosphorus forms in soils receiving manure. Soil Sci. 159, 253-258. https://doi.org/10.1097/00010694-199504000-00004

Soma D. M., Kiba D. I., Ewusi-Mensah N., Gnankambary Z., Lompo F., Sédogo M. P., \& Abaidoo R. C. (2018). Changes in sorghum production, soil P forms and P use efficiency following long-term application of manure, compost and straw in a Ferric Lixisol. Acta Agriculturae Scandinavica, Section B-Soil \& Plant Science, 68(5), 401-411. https://doi.org/10.1080/09064710.2017.1414871

Toor, G. S., Hunger, S., Peak, J. D., Sims, J. T., \& Sparks, D. L. (2006). Advances in the characterization of phosphorus in organic wastes: environmental and agronomic applications. Advances in agronomy, 89, 1-72. https://doi.org/10.1016/S0065-2113(05)89001-7

Walkley, A., \& Black, I. A. (1934). An examination method of the detjareff and a proposed modification of the chromic acid titration method. Soil Science, 37, 29-38. https://doi.org/10.1097/00010694-193401000-00003

\section{Copyright Disclaimer}

Copyright for this article is retained by the author(s), with first publication rights granted to the journal.

This is an open-access article distributed under the terms and conditions of the Creative Commons Attribution license (http://creativecommons.org/licenses/by/4.0/). 